\title{
Infectivity of nematode parasites of the common toad, Duttaphrynus melanostictus (Schneider, 1799) Frost et al., 2006 (Anura: Bufonidae) from different localities of Aurangabad
}

\author{
Sujeet J amdar*, K ishor Shindeand C. J . Hiware \\ Department of Zoology, Dr. Babasaheb Ambedkar Marathwada University, Aurangabad (M.S.), INDIA \\ *Corresponding author. E-mail: Sujeetjamdar@gmail.com \\ Received: M ay 27, 2012; Revised received: J une 26, 2012; Accepted: August 30, 2012
}

Abstract: The common toad, Duttaphrynus melanostictus, Schneider, 1799) Frost et al., 2006 from Aurangabad was found to harbor three species of nematodes; Oswaldocruzia goezei (Skrjabin and Schulz, 1952), Trichuris globusa (V. Linstow, 1901, Ransom, 1911), Oxysomatium macintoshii (Karve, 1927). Among all the parasites, Trichuris globulosa represents the accidental new host record for D. melanostictus in Maharashtra.

Keywords: Duttaphrynus melanostictus, Infectivity, Nematode, Toad

\section{INTRODUCTION}

The host and its parasites constitute a community of organisms living in close intimacy and exerting a profound effect upon each other. The new host record of many helminth parasites of green frogs Rana clamitans Latreille, was found from Southwestern Michigan, (Muzzall et al., 2001). There is also a report on nematode parasites from collection of Zoological survey of India, (Baylis, and Daubney, 1922). Study on intestinal helminths of D uttaphrynus melanostictus from Formosa gave many new host records (Yamaguti and Mitunaga, 1943). The helminth fauna of Andaman and Nicobar islands also studied from India (Soota and Chaturvedi, 1970). Nematode parasites of different species of amphibians from Maharashtra were studied by many workers. Chaudhari and Deshmukh (1977) have reported new species of genus Subcularis from Rana tigrina. The purpose of this study was to report additional species of nematodes in D. melanostictus collected from Aurangabad, Maharashtra.

\section{MATERIALS AND METHODS}

Thirty two $D$. melanostictus including road killed were collected by hand during June 10 to Dec. 2011, from Aurangabad, Maharashtra (12 adult males and 20 adult females) from two collection sites i.e., Site- A University Campus and Site-B Cantonment Area.

Toads were anesthesized with chloroform. The body cavity was opened by a longitudinal ventral incision and the alimentary tract was excised by cutting across the oesophagus and the rectum. Contents of the stomach, small intestine and large intestine were mixed with $0.9 \%$ saline solution and placed in separate petri dishes for examination under a dissecting microscope. The lungs, liver, gall bladder were also examined; some muscles, portions of peritoneum and spinal cord were teased apart with needles and examined. Nematodes were fixed in hot ethanol then stored in mixture of $70 \%$ ethanol and $10 \%$ glycerol and subsequently cleared in glycerol for examination under a compound microscope. Permanent slides were made according to Gibson (1984). Parasites were identified with the use of information from Yamaguti (1961, 1963), "CIH Keys to the Nematode Parasites of Vertebrates" (Anderson, et al., 1974 ab and Anderson, 1978 ) and the "Fauna of British India" (Baylis and Daubney,1922; and Baylis, 1936, 1939).

"Frequency Index" i.e. the percentage of infected hosts per sample and the "Concentration Index" as the number of worms per infected host were calculated (Margolis et al., 1982).

\section{RESULTS AND DISCUSSION}

Helminth parasites, 0 swaldocruzia goezei Skrjabin and Schulz, 1952 (Site: rectum), Trichuris globulosa (Site: stomach and small intestine), Oxysomatium macintoshii Railliet and Henry, 1913 (Site: rectum) were recovered from the gastro-intestinal tract of Duttaphrynus melanostictus (Schneider, 1799, Frost et al., 2006).

Oxysomatium macintoshii. appeared to have a highest frequency index in Site-B (100\%). whereas the lowest frequency index was found in Trichuris globulosa at same Site- B (5.8\%). Similarly the concentration index was highest in 0 xysomatium sp. at Site-B (15par/host) and there was no infection recorded in T. globulosa. from site A (Table 1)

Four nematode species found in this study are common parasites of anurans and occurred in both the localities. 
Table 1. Infectivity of D. melanostictus for helminth parasites from different localities of Aurangabad.

\begin{tabular}{|c|c|c|c|c|c|c|c|c|c|c|}
\hline \multirow{3}{*}{ L ocality } & \multirow{3}{*}{$\begin{array}{l}\text { No. of } \\
\text { Hosts } \\
\text { examined }\end{array}$} & \multicolumn{9}{|c|}{ Parasites recovered } \\
\hline & & \multicolumn{3}{|c|}{ Oswaldocruzia goezei } & \multicolumn{3}{|c|}{ Oxysomatium macintoshii } & \multicolumn{3}{|c|}{ Trichuris globulosa } \\
\hline & & $\begin{array}{c}\text { No. of } \\
\text { hosts } \\
\text { infected }\end{array}$ & $\begin{array}{c}\text { Freq. } \\
\text { index } \\
(\%)\end{array}$ & $\begin{array}{c}\text { Conc. } \\
\text { index } \\
\text { (par/host) }\end{array}$ & $\begin{array}{c}\text { No. of } \\
\text { hosts } \\
\text { infected }\end{array}$ & $\begin{array}{c}\text { Freq } \\
\text { index } \\
(\%)\end{array}$ & $\begin{array}{c}\text { Conc. } \\
\text { index } \\
\text { (par/host) }\end{array}$ & $\begin{array}{c}\text { No. of } \\
\text { hosts } \\
\text { infected }\end{array}$ & $\begin{array}{c}\text { Freq } \\
\text { index } \\
(\%)\end{array}$ & $\begin{array}{c}\text { Conc. } \\
\text { index } \\
\text { (par/host) }\end{array}$ \\
\hline Site- A & 15 & 12 & 80 & 12 & 14 & 93.3 & 14 & - & - & - \\
\hline Site- B & 17 & 15 & 88.23 & 10 & 17 & 100 & 15 & 01 & 5.8 & 01 \\
\hline
\end{tabular}

Among all these species of nematodes only one species i.e. T. globusa exhibited a new accidental records for $D$. melanostictus in the study area.

Amphibians, particularly anurans have a rich parasite fauna (Prudhoe and Bray, 1982) perhaps due to the typical life style of amphibians favouring vulnerability to microbial and parasitic infection. The damp habitats preferred by amphibians favour survival of infective stages of the parasites. This study when compared to the observations of earlier workers suggest that the locality from where the host is collected may account as one of the important factors accounting for variance in frequency index and concentration index of the parasitic fauna in various amphibian populations. This may be due to the fact that an ecological complex is formed at each locus composed of the parasite, the vector, the host and various features of the host's environment which is not something absolute and static, but is ever changing and these factors may account for variance in infectivity as indicated in the present findings.

These results were correlated with previous workers findings such as Prudhoe and Bray (1982), Baylis (1936, 1939), Buchvarov, (1963), Ingles (1936), Soota and Chaturvedi (1971). Thus from the present investigation it was found that Trichuris globulosa, the parasite of ruminant mammals found all over the world and the occurrence in amphibian host forms the first record and it should be considered as an accidental infection.

\section{ACKNOWLEDGEMENT}

The author Mr. Sujeet is very much thankful to the "UGC" for providing the financial assistance by "RFSMS" Scheme and also to the Head Department of Zoology Dr.B.A.M.University, Aurangabad (M.S.) for providing the necessary laboratory facilities during my work.

\section{REFERENCES}

Anderson R. C., Chabaud A.G., Willmott S. (1974a). CIH keys the nematode parasites of vertebrates. No.1. General introduction. Commonwealth Agricultural Bureaux, Farnham Royal, Slough, Headley B rothers L td.

Anderson,R. C., Chabaud, A. G. and Willmott S. (1974b) . CIH keys to the nematode parasites of vertebrates. Commonweatth Agricultural Bureaux, Fornham Royal. Bucks., England.

Anderson, R. C. (1978). Key to the genera of the superfamily Metastrongyloidea. Pp. 1-44. In : Commonwealth Institute of Helminthology keys to the Nematode Parasites of Vertebrates. No.5. Eds. R. C. Anderson, A. G. Chabaud and S. Willmott. Commonwealth Agricultural Bureaux, Farnham, Farnham Royal: England.

Baylis, H.A. and Daubney. R. (1922). Report on the parasitic nematodes in the collection of the Zoological Survey of India. Memories of Indian M useum, Calcutta, 7: 63-347.

Baylis, H.A. (1936). The Fauna of British India including Ceylon and Burma. Nematoda Vol. I (Ascaroidea and Strongyloidea). Originally published by Taylor and Francis, London (reprinted edition : Today \& Tomorrow's Printers $\&$ Publishers, New Delhi). pp 408.

Baylis, H. A. (1939). The Fauna of British India including Ceylon and Burma. Nematoda Vol. II (Filarioidea, Dioctophymoidea and Trichinelloidea). Originally published by Taylor and Francis, London (reprinted edition: Today \& Tomorrow's Printers and Publishers, New Delhi). pp 274 .

Buchvarov, G. (1963). To the helminth fauna of some acaudated amphibians from the Strandzha mountain and the Black sea coast. Scientific works of the H igher Pedagogical Institute of Plovdiv, 2: 1963, pp.69-75.

Choudhari, A. C. and Deshmukh, P.G. (1977). A new species of the genus Subulascaris from Rana tigrina. M arathwada University J ournal of Science (Natural Sciences), 16 (Sci. No. 9) : 85-86.

Frost, D.R., Grant, T., Faivovich, J., Bain, R.H., Haas, A., Haddad, C.F.B., De Sa, R.O., Channing, A., Wilkinson, M., Donnellan, S.C., Raxworthy, C.J., Campbell, J.A., Blotto, B.L., Moler, P., Drewes, R.C., Nussbaum, R.A., Lynch, J.D., Green, D.M. and Wheeler, W.C. (2006). The amphibian tree of life. Bulletin of the American M useum of Natural History, $297: 370$.

Gibson D.I. (1984). Technology as applied to museum collection: the collection, fixation and conservation of helminths. Syst. Parasitol., 6: 241.

Ingles L.G. (1936). Worm parasites of California Amphibia Trans. Amer. Microsc. Soc., 55: 73- 82.

Margolis L.G.W., Esch J.C., Holmes A.M. and Schad G.A. (1982). The use of ecological terms in parasitology. J . Parasitol., 68: 131- 133.

Muzzall P.M., Gillilland M.G., III, Summer C. S. and Mehne C.J. (2001). Helminth communities of green frogs Rana clamitans Latreille, from Southwestern Michigan. J. Parasitol., 87(5): 962-968.

Prudhoe S. and Bray R.A. (1982): Platyhelminth parasites of the Amphibia. Oxford: British M useum (Natural H istory); 0 xford U niversity Press.

Soota, T.D. and Chaturvedi Y. (1971). Notes on some nematodes from the unnamed collections of the Zoological Survey of India. Proc. Zool. Soc., C al cutta, 24: 13- 24. 
Yamaguti, S. and Mitunaga, Y. (1943). Intestinal helminths from Duttaphrynusmelanostictus of Formosa.Transcations of the Natural History Society of F ormosa. Taiwan, 236 (33): 142-154. Yamaguti, S. (1961). Systema Helminthum. Vol. 3 (I \& II). Originally published by Interscience P ublishers, I nc., N ew
York and London (reprinted edition). International Books $\&$ Periodicals Supply Service, New Delhi). pp 679 and 1261.

Yamaguti,S.(1963). Systema Helminthum. Vol.V. Acanthocephala. Interscience, New York. pp 423. 